\title{
Photobiomodulation and physical exercise on strength, balance and functionality of elderly women
}

\author{
Fotobiomodulação e exercício fisíco na força, \\ equilíbrio e funcionalidade de mulheres idosas
}

Fotobiomodulación y ejercicio físico en la fuerza, equilibrio y funcionalidad de mujeres mayores

\section{Patricia Gabrielli Vassão, Renata Luri Toma, Hanna Karen Moreira Antunes, Ana Claudia Muniz Renno*}

\begin{abstract}
Introduction: Aging is associated with structural changes in muscle tissue, which leads to the loss of functional independence. The preservation of the muscle strength through strength training, and recently, low-level laser therapy (LLLT), has high clinical significance. Objective: to investigate the effects of photobiomodulation (PBM $-808 \mathrm{~nm}, 100 \mathrm{~mW}, 35.7 \mathrm{~W} / \mathrm{cm}^{2}$ and $7 \mathrm{~J}$ ) associated with a strength training program on quadriceps muscle strength, balance and functional capacity in elderly women. Methods: Thirty-five healthy women between 60 to 70 years old were divided into two groups: Placebo Group ( $n=13$ ) and Active Group ( $n=14)$. The exercise protocol consisted of knee flexion-extension exercise followed by application of PBM placebo or active, twice a week for 8 consecutive weeks. Results: showed a
\end{abstract}

*PGV: Doctoral student, e-mail: patriciavassao@gmail.com

RLT: PhD, e-mail: renataluri@gmail.com

HKMA: PhD, e-mail: hanna.karen@unifesp.br

ACMR: PhD, e-mail: acmr_ft@yahoo.com.br 
significant increase in 6MWT $(\mathrm{p}=0.001)$, SPPB $(\mathrm{p}=0.006)$ and 1-MR $(\mathrm{p}=0.001)$ in both groups. The strength training program associated with PBM active improved a significant increase, relative to baseline, to the right medial/lateral stability index ( $p=0.007)$ and decrease in the Fall Risk Test $(p=0.005)$. Conclusion: the strength training produced a significant increase of muscle strength and functionality and when combined with the PMB it was significant in the improvement of postural stability and decrease of fall risk.

Keywords: Laser Therapy. Aging. Strength Training. Postural Balance.

\section{Resumo}

Introdução: O envelhecimento está associado a mudanças estruturais no tecido muscular, que levam à perda da independência funcional. A preservação da força muscular através do treinamento de força e, recentemente, da terapia laser de baixa intensidade (TLBI), têm alta significância clínica. Objetivo: investigar os efeitos da fotobiomodulação (808 $\mathrm{nm}, 100 \mathrm{~mW}, 35,7 \mathrm{~W} / \mathrm{cm}^{2}$ e $\left.7 \mathrm{~J}\right)$ associada a um programa de força muscular direcionado à força do músculo do quadríceps, equilíbrio e capacidade funcional de mulheres idosas. Métodos: 35 mulheres saudáveis entre 60 e 70 anos de idade foram divididas em dois grupos: Grupo Placebo (n = 13) e Grupo Ativo ( $n=14)$. 0 protocolo de exercício consistiu no exercício de flexão e extensão de joelhos seguido da aplicação da fotobiomodulação placebo ou ativa, 2 vezes por semana por 8 semanas consecutivas. Resultados: mostraram um aumento significativo no TC6 ( $p=0,001), S P P B(p=0,006)$ e 1-RM $(p=0,001)$ em ambos os grupos. $O$ programa de treinamento de força associado a fotobiomodulação ativa promoveu um significativo aumento relativo à avaliação inicial, no índice de estabilidade medial/lateral direito $(p=0,007)$ e diminuição no Teste de Risco de Queda ( $p=0,005)$. Conclusão: o treinamento de força produziu um significativo aumento da força muscular e da funcionalidade e, quando combinado com a fotobiomodulação, foi significativo em promover estabilidade postural e diminuição do risco de queda.

Palavras-chave: Terapia laser. Envelhecimento. Treinamento de força. Equilíbrio postural.

\section{Resumen}

Introducción: Envejecimiento está asociado a cambios estructurales en el tejido muscular, que llevan a la perdida de la independencia funcional. La preservación de la fuerza muscular a través del entrenamiento de fuerza, y recientemente, la terapia láser de baja intensidad (TLBI), tiene alta significancia clínica. Objetivo: investigar los efectos de la fotobiomodulación (808nm, 100mW, 35,7 W/cm² y 7J) asociado a un programa de fuerza muscular del músculo cuádriceps, equilibrio y capacidad funcional de mujeres mayores. Métodos: 35 mujeres sanas entre 60 y 70 años de edad fueran repartidas en dos grupos: Grupo Ejercicio y Láser Placebo ( $n=$ 13) y Grupo Ejercicio y Láser Activo $(n=14)$. El protocolo de ejercicio consistió en flexión extensión de rodillas seguido de la aplicación de la fotobiomodulación placebo o activa, 2 veces en la semana durante 8 semanas consecutivas. Resultados: mostraron un aumento significativo en el TC6 ( $p=0,001)$, SPPB $(p=0,006)$ y 1-RM ( $p=0,001)$ en los dos grupos. El programa de entrenamiento de fuerza asociado a la fotobiomodulación activa promovió un aumento significativo, relativo a la evaluación inicial, en el índice de estabilidad medial / lateral derecho ( $p=0,007)$ y disminución en la prueba de riesgo de caída $(p=0,005)$. Conclusión: El entrenamiento de fuerza produjo un aumento significativo de la fuerza muscular y funcionalidad, incluso cuando se combinó con la fotobiomodulación fue significativo en promover estabilidad postural y disminución del riesgo de caída.

Palabras clave: Láser Therapy. Aging. Strength Training. Postural Balance. 


\section{Introduction}

Aging is associated to a dynamic and progressive decline of different systems [1]. One of the most relevant impairments, is related to neural and muscular changes, such as the decrease in the number and size of muscle fibers, increased concentrations of catabolic hormones, changes in actomyosin structure and infiltration of adipocytes into muscle fibers [2,3]. These changes cause a decrease in muscle strength and muscle mass that triggers a decline in functional capacity, as well as leads to the increase in the risk of falls and fractures and physical disabilities [2, 4-6].

The functional capacity (FC) refers to the capacity of performing activities of daily living without help, despite the presence of comorbidities $[7,8]$. In the aging process, the evaluation of FC is relevant for clinical assessment, as an indicator of life's quality and also as a planner for medical interventions [9-12].

Physical exercise programs are one of the most effective strategies to increase FC, maintain and improve muscle strength and prevent falls $[13,14]$. This happens because the lack of physical exercise induces anabolic resistance, mitochondrial dysfunction, and apoptosis, and as a vicious cycle, this process generates a state of sarcopenia [15]. Thus, the interruption of this cycle is vital for maintaining the functionality of the elderly people.

The National Health Policy for the Elderly Guideline states the "active and healthy aging", that supports the importance of physical exercise training programs focusing in lower limbs to increase the mobility and maintaining functional independence [7]. Beyond physical exercise, studies have focused on therapeutic interventions capable of attenuating the deleterious effects of aging, resulting in an increase of physical performance and consequent $\mathrm{FC}$, such as photobiomodulation (PBM).

PBM therapy has demonstrated efficacy in muscle bioenergetic activation by promoting photochemical and photophysical events, providing energy availability for cellular activities [16]. The irradiation promotes an increase in cellular metabolism and stimulates the mitochondrial respiratory chain, specifically complex IV, promoting changes in cellular redox status by photodissociation of inhibitory nitric oxide (NO) leading to increased oxygen consumption and activity enzyme ATP production [17].

Previous clinical research demonstrated the positive effects of PBM therapy on muscle including decreased concentration of creatine kinase (CK) and lactate levels, and improved anti-oxidative capacity $[18,19]$ these effects could potentiate muscular performance during physical exercise. Furthermore, the literature described that PBM associated to physical exercise significantly decreases muscular fatigue, increases the number of maximal voluntary contractions and produces a faster muscle recovery in young people [18, 20-23].

Despite all the positive evidences of the association of exercise and PBM on the increase of muscle strength and fatigue levels, there is a lack of studies investigating the effects of PBM from a practical and clinical standpoint. This interaction could prevent muscle fatigue and enhance muscle strength as demonstrated in a previous study $[24,25]$. Moreover, it would provide benefits to improve the functional and balance capacity, within a population.

Therefore, no study focused on physical exercise associated with PBM on balance and FC in older people, thus this study is pioneer. The benefits of PBM associated with a strength-training program would lead to an improved performance and decreased disability and risk of falls.

Based on the positive effects of PBM in muscle tissue, it was hypothesized in this study that PBM would be effective in increasing the quadriceps strength and would concomitantly increase the functional capacity and balance in older women. In this way, we conducted a study to investigate if laser irradiation would provide an additional stimulus to the strength training in the muscle tissue, functional capacity and balance in older women.

\section{Methods}

\section{Subjects}

The present study is a prospective, placebocontrolled, double blind, and randomized clinical trial. Subjects were informed about the purpose and procedures of this study and signed an informed Consent Declaration before their participation in the experiment. Volunteers were recruited through newspaper and radio, from 2013-2014 and were invited to participate in the study. Also, volunteers underwent clinical examination (age, body mass, height, IPAQ) and electrocardiography (EKG) from a physical therapist and an experienced cardiologist, respectively. 
Inclusion Criteria

The inclusion criteria were healthy female aged between 60 and 70 years, BMI between 18 to $27 \mathrm{~kg} / \mathrm{m} 2$ and classified as active, who performed physical activity with a frequency of at least 5 times a week or totaling a minimum of 150 mins per week, according to Criteria established by the International Physical Activity Questionnaire - Short Version (IPAQ), reported by the participants. All volunteers demonstrated medical statements attesting that they were capable to join a program of physical activity.

\section{Exclusion criteria}

Volunteers were excluded from the study if they met any of the following criteria: any previous musculoskeletal injury to the quadriceps femoris, diagnosis of lung diseases, uncontrolled hypertension or diabetes, and orthopedic or rheumatic diseases, fibromyalgia or pain that may prevent the physical exercise. After entering the study, subjects who did not comply properly with the training routine, did not attend two consecutive training sessions or developed any osseous or muscle or articular injuries weren't included.

\section{Randomization}

An experimental design with two groups was used. This study was planned in a prospective, placebo-controlled, double-blind, and randomized clinical trial. The researcher (1) responsible for the randomization was instructed not to communicate the type of treatment given to either the volunteers. The other researcher (2), who applied the laser, was blind to the allocation. To ensure the complete blinding of the researcher (2) who applied the laser, they were instructed not to remain in the laboratory while researcher (1) prepared the laser therapy through an adjustment device. Beside this, a blindfold was used in the laser probe. All volunteers and the researcher responsible for data analysis were blind about the treatments. The volunteers were allocated into one of two groups using a table of random numbers from a computer program (Microsoft Excel 2010). Included volunteers were randomly allocated in Placebo Group
(PG) - subjects who were submitted to strength training and placebo laser or Active Group (AG) subjects who were submitted to strength training and active laser.

\section{Treatment procedure \\ Strength training program}

The first session of the strength training program started 48 hours after the last 1-MR evaluation. All procedures were based on the American College of Sports Medicine Guidelines [13]. Both groups were submitted to a dynamic strength training program that consisted of a knee flexion-extension exercise with 60-80\% 1-MR in a chair (Leg Extension Selection - TechnoGym ${ }^{\circledR}$ ), performed twice a week for 8 consecutive weeks. During the training protocol, every 2 weeks, the 1 -MR was evaluated to adequate the loads to each volunteer. The intensity corresponded to $60 \%$ of $1-\mathrm{MR}$ in the first and second weeks and to $80 \%$ of 1-MR in other weeks [14]. Each session lasted approximately 30 minutes.

\section{PBM Intervention}

Immediately after the end of each session, the $A G$ received active $\mathrm{PBM}$ and $\mathrm{PG}$ received placebo $\mathrm{PBM}$ to the rectus femoris muscle. A laser AsGaAl (Photon Laser III; DMC ${ }^{\circledR}$ São Carlos, SP, Brazil) was used with the following parameters: $\lambda=808 \mathrm{~nm}$, continuous mode, $100 \mathrm{~mW}, 7 \mathrm{~J}$ per point, $56 \mathrm{~J}$ total energy, 0.028 $\mathrm{cm}^{2}$ spot size, $250 \mathrm{~J} / \mathrm{cm}^{2}$ diode energy density or fluency, $35.7 \mathrm{~W} / \mathrm{cm}^{2}$ diode power density and 70 seconds at each point. The irradiation parameters were based on the previous study of Higashi et al. [26]. PBM was applied using the punctual contact technique with beam applied vertically, in 8 points distributed over the muscle belly of the rectus femoris of the dominant limb. In order to standardize the laser application, the treatment points were placed at $25 \%, 35 \%, 50 \%$ and $75 \%$ of the total measurement obtained between the spine anterior superior iliac and superior border of patella, bilaterally, with 2 centimeters of distance between each point. Volunteers used dark laser goggles for eye protection. The dominant limb test [27] determined the lower limb irradiated (PBM placebo or active). 
Assessment Procedure

All participants underwent clinical examination that was performed by the same researcher. The physical therapist that performed the clinical evaluation of the patients was blinded to the group assignment. All the volunteers were evaluated before and after 8 weeks of interventions. The evaluation included:

\section{1-MR Test}

The value of 1-Maximum Repetition (1-MR) was obtained to quantify the strength for knee flexionextension of the volunteers. Before the test, all individuals were familiarized with 3 sessions of the test [28]. For the 1-MR Test, volunteers were instructed to perform one single knee flexion-extension with a maximal contraction force in an extensor chair (Leg Extension Selection - TechnoGym ${ }^{\circledR}$ ) and loads were used to find the maximum load performed in just one repetition. If weight was not determined in the five trials of this session, test was re-scheduled to avoid muscle fatigue influence on determining 1-MR.

\section{Six-minute walk test}

All the volunteers underwent the basal 6MWT to assess functional capacity of exercise. The 6MWT was performed in a 30 meters corridor according to the standardized procedure of the American Thoracic Society [29]. During the test, the patients had to walk 6 minutes at a self-chosen walking speed and they had to try to overcome as much distance as possible, without running.

\section{Short Physical Performance Battery (SPPB)}

SPPB was used to evaluate the performance of lower limbs in three aspects: muscle strength, gait and balance [30]. The test consisted of three small tests: the first assesses static balance in three positions (the feet together in side-by-side, semi-tandem and tandem positions); the second assesses gait speed, timing how long it takes to go three meters at a normal pace; the third evaluates the strength of the lower limbs, clocking time to rise from a chair and return to the seated position five times. Each test score ranges from 0 to 4 , according to the time held in each task. The final score ranges from 0 (dependent) to 12 (good performance).

\section{Balance Test}

The Biodex Balance System SD ${ }^{\circledR}$ (Biodex, New York, EUA) was used to evaluate postural balance. The system is a reliable test for the evaluation of balance in healthy people above 50 years old [31]. In this study, it was used two different protocols, the Fall Risk Test and the Postural Stability Test. Both protocols were adjusted in level 8, for three times with twenty seconds duration each. The volunteers were oriented to keep their eyes open and their hands at the side of their bodies; in case of fall risk they were oriented to keep their hands on sidebars for safety. The software estimates a "Stability Index" from the changes in the center of gravity: the overall stability index (OSI), anterior/posterior stability index (APSI) and medial/lateral stability index (MLSI), in static condition in both and right leg.

\section{Statistical analysis}

All the subjects performed the same evaluations and procedures, except the application of placebo or active PBM. The allocation procedure was concealed from participants and the researcher who applied the laser active or placebo. To evaluate the difference between the variables realized in the groups and evaluations, it was used the analysis of variance model for experiments with repeated measures and the Bonferroni's method for multiple comparisons. The significance level was set at $\mathrm{p} \leq 0.05$.

\section{Results}

Fifty-six volunteers were evaluated. From these, 35 volunteers were selected to participate according to the inclusion criteria and were randomly allocated in two groups: PG and AG. During the period of the study, eight subjects were excluded for the following reasons: six subjects did not attend in two consecutive training sessions and two subjects were sick during training 
program. Thus, the final sample size was 27 volunteers, as shown in Figure 1.

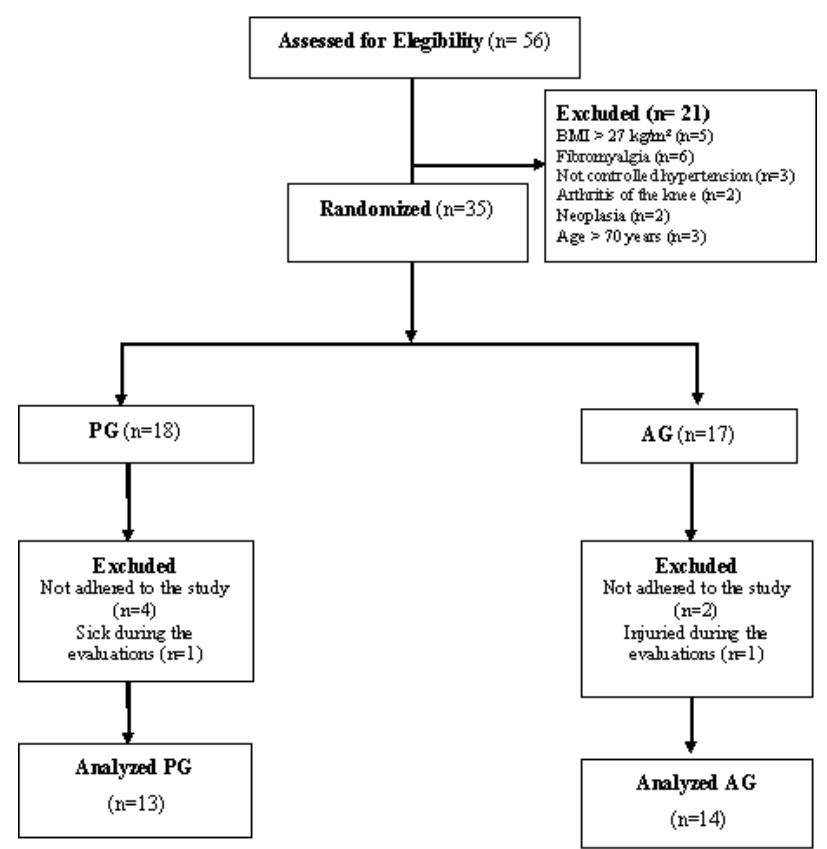

Figure 1 - The Flow Diagram of volunteers' recruitment. BMI: Body Mass Index, PG: Placebo Group, AG: Active Group.

Similar values were found between the two groups in terms of the anthropometrics characteristics for age (y) $63.31 \pm 2.66(\mathrm{PG}) / 64.07 \pm 2.87$ (AG), body mass (kg) $63.31 \pm 8.48(\mathrm{PG}) / 58.87 \pm 9.56(\mathrm{AG})$, height $(\mathrm{m}) 1.54$ $\pm 0.06(\mathrm{PG}) / 1.54 \pm 0.09(\mathrm{AG})$ and $\mathrm{BMI}(\mathrm{kg} / \mathrm{m} 2) 25.03 \pm$ $2.89(\mathrm{PG}) / 24.59 \pm 2.51(\mathrm{AG})$.

In Figure 2, data analysis demonstrated that both groups showed a significant increase of $21.7 \%$ (PG) and 24.8\% (AG) in 1-MR after the strength-training program $(p=0.001)$. However, there was no significant difference between the experimental groups $(p=0.633)$.

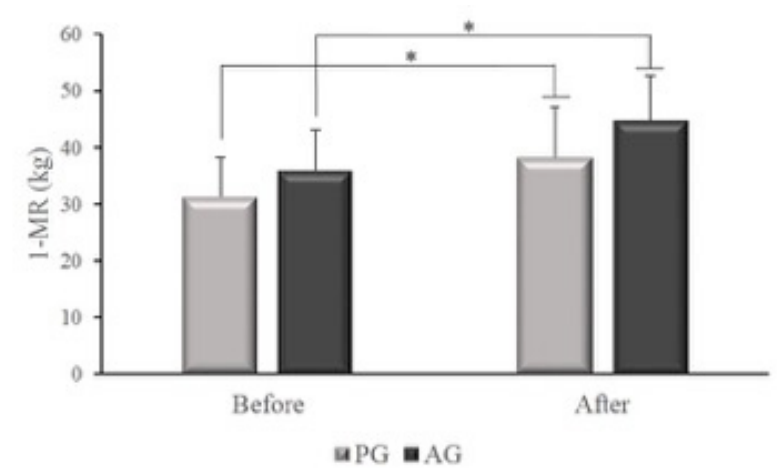

Figure 2 - Values as means and standard deviations of 1-MR (kg).
After the experimental period, the intragroup evaluation demonstrateda significantincrease of $26.6 \%(\mathrm{PG})$ and $40.3 \%$ $(\mathrm{AG})$ in the distance walked in 6MWT $(\mathrm{p}=0.001)$. However, post-training program evaluations showed no significant difference between the groups $(\mathrm{p}=0.175)$ (Figure $3 \mathrm{~A}$ ).

Figure 3B demonstrates in the intragroup evaluation that both groups showed a significant increase of $0.65 \%$ (PG) and 0.91\% (AG) in the SPPB score after strength training program $(p=0.006)$.Nevertheless, there wasno significant differencein SPPB betweengroupsintheintergroupevaluation $(\mathrm{p}=0.534)$.

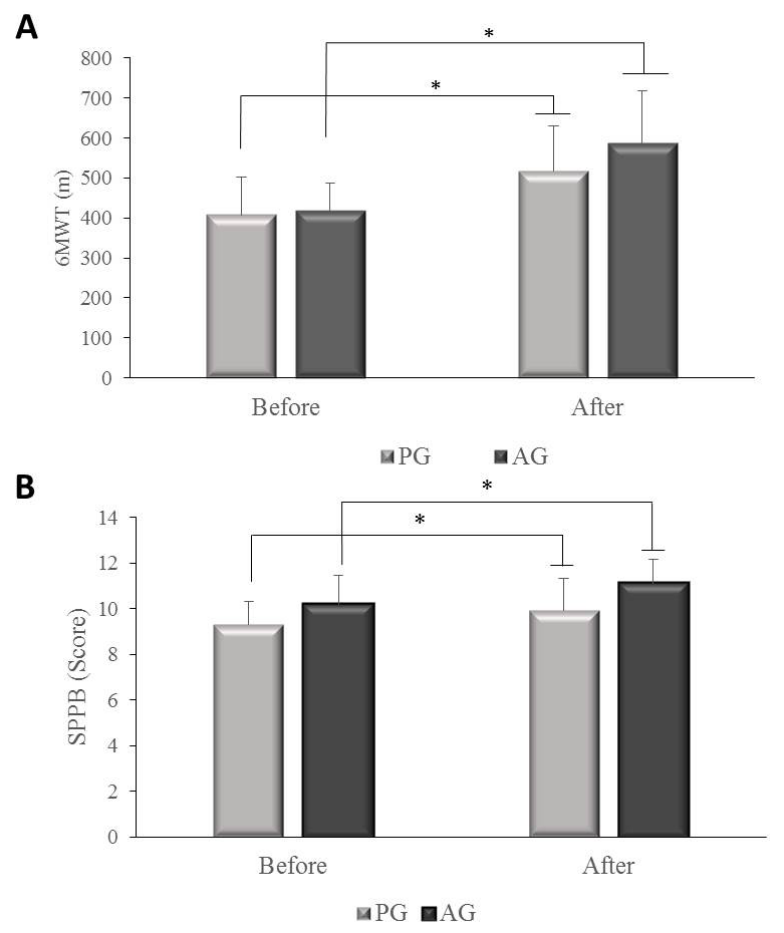

Figure 3 - A) Values as means and standard deviations of 6MWT (m). B) Values as means and standard deviations of SPPB.

The Fall Risk Test demonstrated that the AG significantly decreased this index after the strengthtraining program $(\mathrm{p}=0.005)$, whereas the $\mathrm{PG}$ did not show a significant difference $(p=0.775)$ (Figure 4$)$.

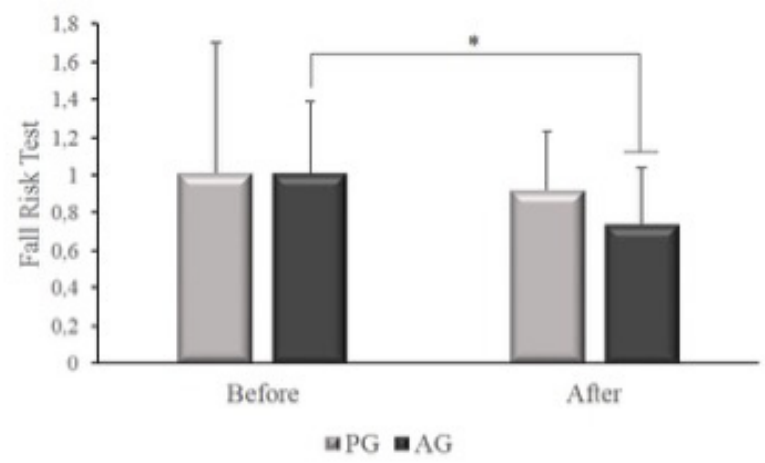

Figure 4 - Values as means and standard deviations of Fall Risk Test. 
The Postural Stability Test indexes are shown in Table 1. The variables evaluated did not demonstrate an intergroup difference after strength training program $(\mathrm{p}=0.192)$. In the intragroup analysis, only the active laser group had a significant improvement on medial/ lateral direction in right leg $(\mathrm{p}=0.007)$.

Table 1 - Stability Indexes data

\begin{tabular}{ccccc}
\hline & \multicolumn{2}{c}{ Placebo } & \multicolumn{2}{c}{ Active } \\
\hline Variables & Before & After & Before & After \\
\hline OSI-Both & $0.86 \pm 0.57$ & $0.85 \pm 0.35$ & $0.92 \pm 0.39$ & $0.74 \pm 0.27$ \\
APSI-Both & $0.59 \pm 0.49$ & $0.59 \pm 0.30$ & $0.69 \pm 0.31$ & $0.54 \pm 0.23$ \\
MLSI-Both & $0.48 \pm 0.27$ & $0.46 \pm 0.28$ & $0.46 \pm 0.29$ & $0.38 \pm 0.17$ \\
OSI-Rigth & $1.56 \pm 0.73$ & $1.61 \pm 0.78$ & $1.63 \pm 0.59$ & $1.36 \pm 0.96$ \\
APSI-Rigth & $1.10 \pm 0.61$ & $1.10 \pm 0.97$ & $0.98 \pm 0.61$ & $1.07 \pm 0.49$ \\
MLSI-Right & $1.06 \pm 0.51$ & $1.02 \pm 0.76$ & $0.88 \pm 0.52^{\star}$ & $0.54 \pm 0.34^{*}$ \\
\hline
\end{tabular}

NOTE: Values are mean \pm SD or as otherwise indicated.

${ }^{*} p \geq 0.05$, before vs after strength training program. Abbreviations: OSI: overall stability index; APSI: anterior/posterior stability index; MLSI: medial/lateral stability index.

\section{Discussion}

The present work investigated the effects of PBM associated with strength training on muscle strength, functional capacity and balance in older women. The results showed that both experimental groups (placebo and active) presented an improvement of the muscle strength and functional capacity after the strength-training program. However, no difference was observed between the two groups at the end of the experimental period (intergroup evaluation). Interestingly, the Fall Risk Test and Postural Stability Test demonstrated that only the trained active irradiated group had a significant decrease in the risk of falls and in the stability index of medial/lateral direction in the right leg after the experimental period.

In this study, a significant increase of 1-MR values was observed for both experimental groups, without any statistical significant difference between the active and placebo lasers. Despite this lack of statistical difference between groups, the percentage of increase for the active group was higher than the placebo group, indicating a tendency of positive effect of PBM on the stimulation of trained muscle tissue. Ferraresi et al. [32] observed a significant increase in muscle strength in trained irradiated healthy men measured trough the leg-press evaluation. Moreover, Toma et al. [24] observed that the mean number of repetitions performed during a fatigue protocol was higher when older volunteers received active PBM in comparison to the condition using placebo irradiation. In the study, the tendency of higher 1 -MR values in the laser-trained irradiated women may be related to the stimulatory effect of PBM on cellular bioenergetics and ATP synthesis, which contribute to the increased of cellular energy [16, 22, 32].

Furthermore, the 6MWT showed that both groups performed higher values of distance walked after the experimental protocol when compared to the basal data. Our results support the statement of the positive effects of strength training for the improvement of the functional capacity in older people [33]. In 1-MR evaluation, the laser-trained group showed a higher increase in the percentage of the distance walked in the 6MWT when compared to the trained-only group (increase of $40.3 \%$ and $26.6 \%$, respectively). Ferraresi et al. [32] state that PBM is capable of accelerating the removal of lactic acid produced during exercise, contributing to lower lactate accumulation and increased energy availability during exercise. This fact, associated to higher muscle metabolism, may be responsible for the longer distance walked in trained-irradiated volunteers.

Data from the SPPB evaluation demonstrated that both groups had an improvement of the functional ability in the lower limbs, which is probably related to the increase in lower limb muscle strength due to the exercise training. The improvement in the capacity of performing functional activities influences the ability in ADL, improving the quality of life [2]. In the same way, PBM did not have any extra effect on the parameters evaluated by SPPB when compared to the trained-only group. 
The Fall Risk Test demonstrated that the lasertrained group presented significantly better results than the other group, demonstrating a decrease in the risk of falls in the AG. This test is effective in measuring the risk of falls [34]. Furthermore, according to Scott et al. [35] the quadriceps muscle strength is a clinically relevant predictor of risk of falls and it is well established that a stronger quadriceps contributes to the decrease of the rate of falls in older people. Additionally, a previous study demonstrated the positive correlation between balance and quadriceps strength in osteoporotic older women [36]. Thus, the improved result presented by AG in this test may be related to the higher percentage of quadriceps strength gain.

The evaluation of the Postural Stability Test demonstrated that only the active irradiated group had a significant improvement on medial/lateral direction in right leg ( $p=0.007)$. Medial/lateral stability index assess the horizontal fluctuations along the medial lateral axes [37]. In a previous study, the increased amount of oscillation in the medial/lateral direction was a sensitive predictor for functional capacity of older individuals [38]. In this context, it can be suggested that the association of the strength training and laser irradiation produced an improvement in the motor units recruitment and in the firing frequency of motor neurons, culminating in the enhancement of this variable and consequently, in the functional capacity [23].

The PBM parameters used in this study were based on previous studies that demonstrated positive effects of irradiation in muscle performance in older women after a fatigue protocol [24,39]. In this study, the infrared wavelength was used based on its higher penetration power compared to red wavelengths [40].

As exposed above, it is of high importance to study strategies to increase muscle strength and performance in older people, decreasing the risk of falls and mortality [14]. Given the aging of population, the related benefits of PBM associated with a strength training program would provide not only a higher muscle performance and lower incidence of falls but also, improvement in quality of life. The present study was a pioneer in investigating the effects of PBM on strength and functional parameters in older people.

\section{Study limitations}

PBM was applied in only one of the lower limbs, although both lower limbs have been involved in all evaluations; the area of irradiation and time spent for therapy were long, due to the spot diameter and area used in PBM being small. Additionally, our study contained short-term effects; thus, other studies should investigate the long-term effects of PBM.

\section{Conclusion}

In this study, the exercise program (associated or not with $\mathrm{PBM}$ ) produced an increase in the muscle strength and functional capacity. Further, the association of strength training and active PBM showed a significant improvement in medial/lateral Postural Stability of right leg and decrease in Fall Risk, demonstrating the positive evidences of these treatments in older women. Those findings open a window to clinical applications; however, more studies are necessary to clarify the parameters of PBM and their application in elderly people.

\section{Acknowledgments}

We would like to thank the support of the Brazilian funding agency: São Paulo State Foundation for Research (Fapesp).

\section{References}

1. Manini TM, Clark BC. Dynapenia and aging: an update. J Gerontol A Biol Sci Med Sci. 2012;67(1):28-40.

2. Clark BC, Manini TM. Functional consequences of sarcopenia and dynapenia in the elderly. Curr Opin Clin Nutr Metab Care. 2010;13(3):271-6.

3. Fragala MS, Kenny AM, Kuchel GA. Muscle quality in aging: a multi-dimensional approach to muscle functioning with applications for treatment. Sports Med. 2015;45(5):641-58.

4. Silva JP, Pereira DS, Coelho FM, Lustosa LP, Dias JM, Pereira LS. Clinical, functional and inflammatory factors associated with muscle fatigue and self-perceived fatigue in elderly community-dwelling women. Rev Bras Fisioter. 2011;15(3):241-8.

5. Silva AT, Duarte YA, Santos JL, Wong, R, Lebrão ML. Prevalence and associated factors of sarcopenia among elderly in Brazil: findings from the SABE study. J Nutr Health Aging. 2014;18(3):284-90. 
6. Arnold P, Bautmans I. The influence of strength training on muscle activation in elderly persons: a systematic review and meta-analysis. Exp Gerontol. 2014;58:58-68.

7. Organização Mundial De Saúde. Envelhecimento ativo: uma política de saúde. Brasília: Organização PanAmericana de saúde; 2005.

8. Cardoso JH, Costa JSDC. Características epidemiológicas, capacidade funcional e fatores associados em idosos de um plano de saúde. Cienc Saude Coletiva. 2010;15(6):2871-8.

9. Nogueira SL, Ribeiro RCL, Rosado LEFPL, Franceschini SCC, Ribeiro AQ Pereira ET. Fatores determinantes da capacidade funcional em idosos longevos. Rev Bras Fisioter. 2010;14(4):322-9.

10. Nunes MCR, Ribeiro RCL, Rosado LEFPL, Franceschini SC. Influência das características sociodemográficas e epidemiológicas na capacidade funcional de idosos residentes em Ubá, Minas Gerais. Rev Bras Fisioter. 2009;13(5):376-82.

11. Alves LC, Leimann BCQ, Vasconcelos MEL, Carvalho MS, Vasconcelos AGG, Fonseca TCO, et al. A influência das doenças crônicas na capacidade funcional dos idosos do Município de São Paulo, Brasil. Cad Saude Publica. 2007;23(8):1924-30.

12. Parahyba MI, Veras R, Melzer D. Incapacidade funcional entre as mulheres idosas no Brasil. Rev Saude Publica. 2005;39(3):383-91.

13. American College of Sports Medicine. ACSM's resource manual for guidelines for exercise testing and pre-scription. Philadelphia, PA: Lippincott Williams \& Wilkins; 2003.

14. Mayer F, Scharhag-Rosenberger F, Carlsohn A, Cassel M, Müller S, Scharhag J. The intensity and effects of strength training in the elderly. Dtsch Arztebl Int. 2011;108(21):359-64.

15. Herrero AC, Cadore EL, Velilla NM, Redin MI. Physical exercise in the frail elderly: an update. Rev Esp Geriatr Gerontol. 2015;50(2):74-81.

16. Karu T. Mitochondrial mechanisms of photobiomodulation in context of new data about multiple roles of ATP. Photomed Laser Surg. 2010;28(2):159-60.
17. Hamblin MR. Mechanisms and applications of the antiinflammatory effects of photobiomodulation. AIMS Biophys. 2017;4(3):337-61.

18. Leal Jr EC, Lopes-Martins RA, Vanin AA, Baroni BM, Grosselli D, De Marchi T, etal. Effect of $830 \mathrm{~nm}$ low-level laser therapy in exercise-induced skeletal muscle fatigue in humans. Lasers Med Sci. 2009;24(3):425-31.

19. De Marchi T, Leal Jr EC, Bortoli C, Tomazoni SS, LopesMartins RA, Salvador M. Low-level laser therapy (LLLT) in human progressive-intensity running: effects on exercise performance, skeletal muscle status, and oxidative stress. Lasers Med Sci. 2012;27(1):231-6.

20. Leal Jr EC, Lopes-Martins RA, Dalan F, Ferrari M, Sbabo FM, Generosi RA, et al. Effect of 655-nm low-level laser therapy on exercise-induced skeletal muscle fatigue in humans. Photomed Laser Surg. 2008;26(5):419-24.

21. Baroni BM, Leal Jr EC, De Marchi T, Lopes AL, Salvador M, Vaz MA. Low level laser therapy before eccentric exercise reduces muscle damage markers in humans. Eur J Appl Physiol. 2010;110(4):789-96.

22. VieiraWH,Ferraresi C,PerezSE, Baldissera V,Parizotto NA. Effects of low-level laser therapy ( $808 \mathrm{~nm}$ ) on isokinetic muscle performance of young women submitted to endurance training: a randomized controlled clinical trial. Lasers Med Sci. 2012;27(2):497-504.

23. Maciel TS, Muñoz IS, Nicolau RA, Nogueira DV, Hauck LA, Osório RA, et al. Phototherapy effect on the muscular activity of regular physical activity practitioners. Lasers Med Sci. 2014;29(3):1145-52.

24. Toma RL, Tucci HT, Antunes HK, Pedroni CR, Oliveira AS, Buck I, etal. Effect of $808 \mathrm{~nm}$ low-level laser therapy in exercise-induced skeletal muscle fatigue in elderly women. Lasers Med Sci. 2013;28(5):1375-82.

25. Paolillo FR, Corazza AV, Paolillo AR, Borghi-Silva A, Arena $\mathrm{R}$, Kurachi $\mathrm{C}$, et al. Phototherapy during treadmill training improves quadriceps performance in postmenopausal women. Climacteric. 2014;17(3):285-93.

26. Higashi RH, Toma RL, Tucci HT, Pedroni CR, Ferreira PD, Baldini G, et al. Effects of low-level laser therapy on biceps braquialis muscle fatigue in young women. Photomed Laser Surg. 2013;31(12):586-94. 
27. Ruiter CJ, Korte A, Schreven S, Haan A. Leg dominancy in relation to fast isometric torque production and squat jump height. Eur J Appl Physiol. 2010;108(2):247-55.

28. Nascimento MA, Januário RS, Gerage AM, Mayhew JL, Pina FLC, Cyrino ES. Familiarization and reliability of one repetition maximum strength testing in older women. J Strength Cond Res. 2013;27(6):1636-42.

29. ATS Committee on Proficiency Standards for Clinical Pulmonary Function Laboratories. ATS statement: guidelines for the six-minute walk test. Am J Respir Crit Care Med. 2002;166(1):111-7.

30. Nakano MM, Otonari TS, Takara KS, Carmo CM, Tanaka C. Physical performance, balance, mobility, and muscle strength decline at different rates in elderly people.J Phys Ther Sci. 2014;26(4):583-6.

31. Cho KH, Bok SK, Kim YJ, Hwang SL. Effect of Lower Limb Strength on Falls and Balance of the Elderly. Ann Rehabil Med. 2012;36(3):386-93.

32. Ferraresi C, Oliveira TB, Zafalon LO, Reiff RBM, Baldissera $\mathrm{V}$, Perez SEA, et al. Effects of low level laser therapy (808 nm) on physical strength training in humans. Lasers Med Sci. 2011;26(3):349-58.

33. Hunter GR, McCarthy JP, Bamman MM. Effects of resistance training on older adults. Sports Med. 2004;34(5):329-48.

34. Wiszomirska I, Krynicki B, Kaczmarczyk K, Gajewski J. The impact of functional training on postural stability and body composition in women over 60. J Sports Med Phys Fitness. 2015;55(6):654-62.
35. Scott D, Stuart AL, Kay D, Ebeling PR, Nicholson G, Sanders KM. Investigating the predictive ability of gait speed and quadriceps strength for incident falls in community-dwelling older women at high risk of fracture. Arch Gerontol Geriatr. 2014;58(3):308-13.

36. Carter ND, Khan KM, Mallinson A, Janssen PA, Heinonen A, Petit MA, et al. Knee extension strength is a significant determinant of static and dynamic balance as well as quality of life in older community-dwelling women with osteoporosis. Gerontology 2002;48(6):360-8.

37. Arnold BL, Schmitz RJ. Examination of balance measures produced by the biodex stability system. J Athl Train. 1998;33(4):323-7.

38. Williams HG, McClenaghan BA, Dickerson J. Spectral characteristics of postural control in elderly individuals. Arch Phys Med Rehabil. 1997;78(7):737-44.

39. Vassão PG, Toma RL, Antunes HK, Tucci HT, Renno AC. Effects of photobiomodulation on the fatigue level in elderly women: an isokinetic dynamometry evaluation. Lasers Med Sci. 2016;31(2):275-82.

40. Enwemeka CS. Intricacies of dose in laser phototherapy for tissue repair and pain relief. Photomed Laser Surg. 2007;27(3):387- 93.
Received in 01/16/2018

Recebido em 16/01/2018

Approved in 02/26/2018

Aprovado em 26/02/2018 